A SHORT HISTORY OF WOOL AND ITS MANUFACTURE 



\title{
A SHORT HISTORY
}

OF WOOL

AND

\section{ITS MANUFACTURE \\ (MAINLY IN ENGLAND)}

\author{
BY \\ E. LIPSON
}

'I thanke God, and ever shall,

It is the Sheepe hath payed for all.'

HARVARD UNIVERSITY PRESS

CAMBRIDGE, MASSAGHUSETTS

I 953 
PRINTED IN GREAT BRITAIN 